\title{
Comfortable Urban Environment as a Factor of Regional Tourism Development
}

\author{
Yakovlev Andrey \\ Faculty "Higher School of Management", Financial University under the Government of the Russian \\ Federation, Moscow, Russia
}

\begin{abstract}
ANNOTATION
Research problem and degree of the research: The study is devoted to identifying the influence of the quality of the urban environment as a factor in the development of tourism in the regions. Domestic tourism, as the experience with COVID-19 has shown, becomes both an engine of economic development of regions, and a solution to the problem of lack of opportunities or health safety when traveling abroad.

Problematic issue: What is a comfortable urban environment as a factor in the development of tourism in the region? The article considers one of the factors influencing the development of tourism in Russian cities. Therefore, if we consider the influence of this factor and focus it also on tourists, we can accelerate the development of the industry. This factor is a comfortable urban environment.
\end{abstract}

Subject of the article: Comfortable urban environment development.

The purpose of the study: is to identify the patterns between the level of development of the urban environment and the development of tourism in the regions and their tourist attractiveness.

Research methods: statistical analysis of open data of the Federal Tourism Agency by region, comparative quantitative analysis of the quality of the urban environment and the development of tourism in the regions, general scientific research methods. The article provides a quantitative analysis of the quality indices of the urban environment of cities and regions, and uses its own methodology for calculating the tourist attractiveness of regions as domestic tourist destinations.

The study did not reveal a direct relationship between the quality of the urban environment and the tourist attractiveness of the regions. However, there is a reason that the quality of the urban environment has an indirect impact on these indicators: tourists do not go directly to "see" the urban environment, but the development of the urban network and urban infrastructure has a positive impact on the level of attractiveness and tourism.

The study leaves several open questions, including changing the approach to assessing the attractiveness of regions, identifying the elements that most affect tourist preferences and impressions from the method of calculating the urban quality index, how much influence is the time lag between the beginning of the development of a comfortable urban environment and the first results in the form of a growing tourist flow (the index is calculated from 2018; the priority project was approved in 2016).

Key words: comfortable urban environment, tourist attractiveness, factors of development.

\section{INTRODUCTION}

Relevance and novelty: In the 21 st century, tourism has come to play an important role in the global economy - its share of global GDP reached $10.4 \%$ in 2019 , and tourism and related industries employed more than 300 million people. These data justify the great attention to the tourism sector on the part of business and the state, which constantly stimulates the development of the industry because tourists leave their money in the country's economy. The issues of tourism research are more relevant than ever after the pandemic that hit the world and its consequences in the form of the fall of the tourism and hospitality industry.

Problematic issue: What is a comfortable urban environment as a factor in the development of tourism in the region? The article considers one of the factors influencing the development of tourism in Russian cities. Therefore, if we consider the influence of this factor and focus it also on tourists, we can accelerate the development of the industry. This factor is a comfortable urban environment.

Subject of the article: Comfortable urban environment development. 
The aim: To reveal a comfortable urban environment as a factor in the development of tourism in the region.

Research methods and methodology: Statistical analysis of open data of the Federal Tourism Agency by region, comparative quantitative analysis of the quality of the urban environment and the development of tourism in the regions, general scientific research methods. The article provides a quantitative analysis of the quality indices of the urban environment of cities and regions, and uses its own methodology for calculating the tourist attractiveness of regions as domestic tourist destinations.

\section{DEFINING THE URBAN ENVIRONMENT}

There is no single interpretation of the concept of "urban environment". In foreign practices, broader ones are used - liveability and quality of life, which are a wide set of different elements that take into account the entire external environment. According to Britannica, quality of life is the degree to which a person is healthy (meaning physical, mental, etc., replaced by "well-being", "well-being"), feels comfortable in life, and is able to enjoy it. By definition, it is clear that it is very broad and quite subjective - people have different degrees of perception of their level and quality of life.

This combination of factors dissolves the influence of the urban environment (or rather its comfort) on the assessment of satisfaction with the quality of life. Therefore, the indicators of world practice are not applicable in the context of the study.

In Russian practice, there is no single approach to the definition of the urban environment: neither researchers nor legislators. Based on the passport of the State Priority Project "Formation of a comfortable urban environment", it can be assumed that the Government of the Russian Federation understands the urban environment as a single space, or the territory of the city, which includes various elements that make up the functioning of the city, which are evaluated according to the following criteria: safety, comfort, functionality, and aesthetics. The research of the official documents on the legislative definition of the urban environment did not reveal a precise and unified approach.

According to research by The Boston Consulting Group (BCG) (Безрукова, Бутенко, Ермаков et al., 2017), the urban environment consists of six elements, identified based on a common interpretation adopted in Russian practice: Housing and yard Pedestrian infrastructure; Security level; External attractiveness and uniqueness; Well-being of public spaces; Leisure, sports, entertainment, and cultural life. These elements, in turn, are grouped into three categories: House and Yard, Transit Spaces, and Points of Attraction.

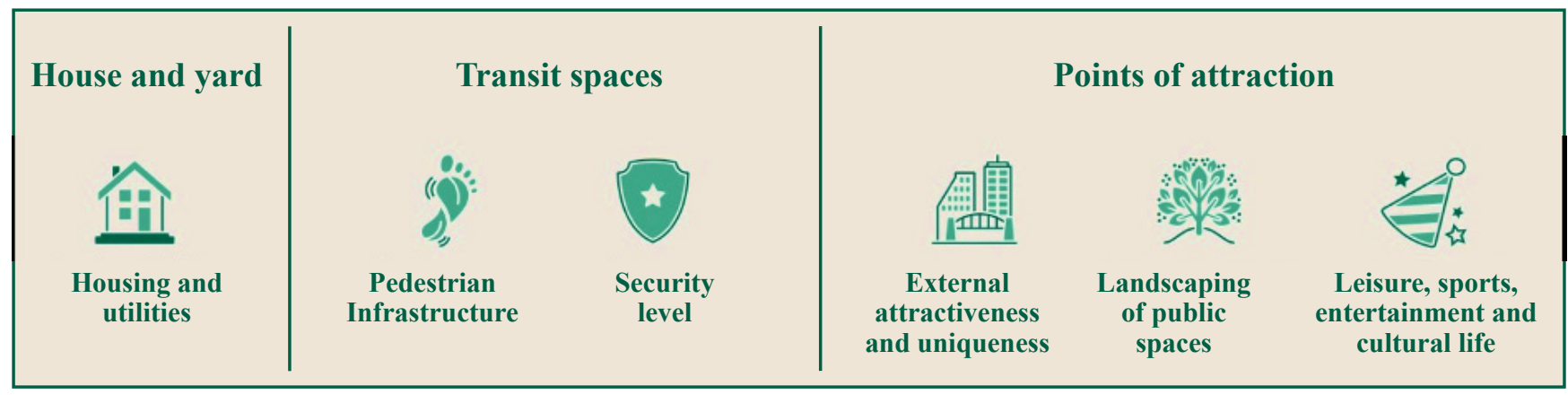

Figure 1. Six elements of the urban environment (Source: Безрукова, Бутенко, Ермаков, 2017) 
House and yard are the places associated with the place of residence of citizens. Transit spaces the movement of citizens from one object to another (excluding personal and public transport). Points of attraction - places used by citizens for spending time outside the house.

Another approach is used in the Urban Environment Quality Index, created during the implementation of the project "Creating a comfortable Urban Environment".

The measurement methodology is as follows: the city consists of six spaces (they are not mutually exclusive, that is, they can intersect):

1. Housing and adjacent spaces - multi-apartment residential buildings and individual residential sector;

2. Green spaces - parks, squares, gardens, etc.;

3. Public and business infrastructure and adjacent spaces - objects of services and services, public catering, administrative and business objects;

4. Social and leisure infrastructure and surrounding areas-educational, medical, cultural institutions, as well as sports, leisure, and recreation;

5. Street and road network - streets, roads;

6. Citywide space - the whole city.

Based on two approaches, it is possible to determine within the framework of this study that the urban environment is a set of elements of the life of citizens: places of residence, work, pastime, recreation, entertainment within the city boundaries, as well as their condition, quantitative and qualitative assessment by residents and authorities.

\section{COMFORTABLE URBAN ENVIRONMENT AS A FACTOR OF TOURISM DEVELOPMENT}

The influence of the urban environment factor must be taken into account for the reason that it is an integral part of the tourist destination, the development of which determines the tourist flow, the attractiveness of the territory, the attendance, and the state of tourism-related industries-accommodation facilities (hotels, hostels), public catering.

Even though the primary criterion of satisfaction with a trip is the quality of the tourist product and the assessment of the rest and the entire destination should depend more on it, there are other criteria. The tourism industry has its specific characteristics: for example, the basis of the offer is not the service itself, but the impression that the tourist receives. Therefore, the travel industry is called one of the main elements of the experience industry.

In the course of the study, a hypothesis is put forward: that the high level of comfort of the urban environment has a positive impact on the development of tourism and is a competitive advantage of the territory, the city.

We proceed from the assumption that a comfortable urban environment creates an overall impression of the trip, as it expands the possibilities for learning about the destination - to go beyond the boundaries of "tourist areas" (for example, the historical center of Istanbul). With a high level of development of the urban environment, the distance of tourist penetration into the city increases distance from attractions, which in turn reduces the differentiation of the development of tourist and non-tourist areas of the city. 
However, not all the elements of the urban environment identified by the BCG and taken into account in the Urban Environment Quality Index are important for tourists: some have a lot of weight, some almost none. So, for example, housing and utilities, business spaces have little impact, since they do not fall into the field of view of tourists who are non-residents of the city.

\section{COMPARISON OF THE LEVELS OF THE URBAN ENVIRONMENT OF THE REGIONS}

To identify the relationship between two values - the tourist attractiveness of the region and the level of the urban environment - four regions of Russia were compared in pairs. The open data of the Federal Agency for Tourism, i.e., the number of Russian citizens placed in collective accommodation facilities, was used as the value of tourist attractiveness.

When choosing an approach to comparing cities, the model of functional urban space was used by D. Burtenshaw, M. Bateman \& G. J. Ashworth (1991). According to Bartenshaw's theory, a city as a destination (tourist territory) is a final product that includes seven active spaces: historical, cultural, sports, business, night (Nightlife City), shopping, and tourist, which covers almost completely the previous ones (Ashworth, Page, 2011). The urban space itself is created in the process of communication between different groups of users in different spaces and the use of urban resources. Urban resources are the products of the activities of spaces.

In our case, the user group is tourists who consume almost all of the city's resources. Therefore, to compare the tourist component of the two regions, it is necessary to choose those that relate to each other in terms of the number of resources that interest tourists: historical resources, culture, entertainment those that leave an impression of rest.

The basis for choosing the regions was the number of their attractions, which are taken into account by the Federal Tourism Agency. The first two regions have an almost equal total number of attractions, for outdoor activities, culture, museums, entertainment and theaters.

In addition, the population in the regions is almost the same (2.62 million people - Perm Krai; 2.79 million - Novosibirsk region), including the share of the urban population.

Table 1. Comparison of urban resources in the tourism sector of the Perm Region and the Novosibirsk region

\begin{tabular}{|l|c|c|c|c|c|c|}
\hline Regions & Total number & Active recreation & Culture & Museums & Entertainment & Theaters \\
\hline the Perm Region & 662 & 61 & 147 & 71 & 53 & 20 \\
\hline $\begin{array}{l}\text { the Novosibirsk } \\
\text { region }\end{array}$ & 500 & 52 & 169 & 70 & 57 & 18 \\
\hline
\end{tabular}

Source: Open Data of the Federal Tourism Agency

The Kursk region and the Chuvash Republic are also similar in the number of urban resources and population: 1.12 million and 1.24 million people of the total population and 671.9 thousand and 770.7 thousand people of the urban population, respectively. 
Table 2. Comparison of urban resources in the field of tourism in the Kursk region and the Chuvash Republic

\begin{tabular}{|l|c|c|c|c|c|c|}
\hline Regions & Total number & Active recreation & Culture & Nature & Entertainment & Traditions \\
\hline the Chuvash Republic & 118 & 11 & 28 & 9 & 13 & 4 \\
\hline the Kursk region & 190 & 11 & 35 & 9 & 13 & 11 \\
\hline
\end{tabular}

Source: Open Data of the Federal Tourism Agency

\section{RESEARCH RESULTS AND DISCUSSION}

Novosibirsk region and Perm Krai.

According to Open sources of the Federal Tourism Agency, the number placed in the collective means of accommodation of citizens of Russia in the Novosibirsk region in 2018-2019 was higher than the rates in the Perm region at $38-39 \%$, even though the total area of the room Fund of collective accommodation facilities in the Novosibirsk region Perm was higher by $16-20 \%$ for the same period (See Table. 3 ).

Table 3. Comparison of the number of people placed and the area of the number fund for the 2018 - 2019 year of the Novosibirsk region and the Perm krai

\begin{tabular}{|l|c|c|c|c|}
\hline & \multicolumn{2}{|c|}{ Number of people placed, pers. } & \multicolumn{2}{c|}{ The area of the number fund, $\mathbf{m}^{\mathbf{2}}$} \\
\hline Regions & $\mathbf{2 0 1 8}$ & $\mathbf{2 0 1 9}$ & $\mathbf{2 0 1 8}$ & $\mathbf{2 0 1 9}$ \\
\hline the Novosibirsk region & 983053 & 1029796 & 259393 & 273892 \\
\hline the Perm Region & 710633 & 736528 & 221852 & 227316 \\
\hline
\end{tabular}

Source: Open Data of the Federal Tourism Agency

Based on the data, it can be assumed that the Novosibirsk region is more attractive for travelers than the Perm Region since the difference in the number of people placed over the past two years is higher than the difference in the ability to accommodate tourists.

However, when considering the quality indices of the urban environment, the Novosibirsk region lags significantly behind the Perm Region - the average score of the Novosibirsk region is 152 out of 360, and for the Perm Region, 172 for 2020. Of the 25 cities in the Perm Region, 4 have a favorable urban environment, and only one of the 16 cities in the Novosibirsk Region.

The Kursk region and the Chuvash republic.

When comparing the Kursk region of Chuvash Republic, the following data were obtained: even though for the 2018 - 2019 year, the number placed in the Chuvash Republic exceeds the same indicator of the Kursk region 44 of $50 \%$, the area of the room stock in Chuvashia only slightly bigger $6-7 \%$ (see table 4 ).

Table 4. Comparison of the number of people placed and the area of the number fund for the 2018 - 2019 year of the Kursk region and the Chuvash Republic

\begin{tabular}{|l|c|c|c|c|}
\hline & \multicolumn{2}{|c|}{ Number of people placed, pers. } & \multicolumn{2}{c|}{ Room area, $\mathbf{m}^{\mathbf{2}}$} \\
\hline Regions & $\mathbf{2 0 1 8}$ & $\mathbf{2 0 1 9}$ & $\mathbf{2 0 1 8}$ & $\mathbf{2 0 1 9}$ \\
\hline the Kursk region & 186803 & 200332 & 81280 & 81907 \\
\hline the Chuvash Republic & 268960 & 300574 & 87268 & 87111 \\
\hline
\end{tabular}

Source: Open Data of the Federal Tourism Agency 
Based on these data, it can be assumed that the tourist attractiveness and level of tourism development in the Chuvash Republic as a whole are higher than that of the Kursk region, since the number of Russian citizens who are located in the collective accommodation facilities of the republic is much higher than that of the Kursk region.

This assumption is also confirmed by the quality of the urban environment of the regions: the average level of quality of the urban environment of Chuvashia from 2018 to 2020 increased from 179 points to 192, while in the Kursk region — from 169 to 181.

\section{CONCLUSIONS AND PERSPECTIVES}

Thus, the study did not reveal a direct relationship between the quality of the urban environment and the tourist attractiveness of the regions. However, there is a reason that the quality of the urban environment has an indirect impact on these indicators: tourists do not go directly to "see" the urban environment, but the development of the urban network and urban infrastructure has a positive impact on the level of attractiveness and tourism.

However, the study leaves several open questions, including changing the approach to assessing the attractiveness of regions, identifying the elements that most affect tourist preferences and impressions from the method of calculating the urban quality index, how much influence is the time lag between the beginning of the development of a comfortable urban environment and the first results in the form of a growing tourist flow (the index is calculated from 2018; the priority project was approved in 2016).

When answering these questions, the comfortable urban environment will be studied in more detail as a factor in the development of tourism and the tourist attractiveness of cities and regions.

\section{REFERENCES}

1. Ashworth, G., \& Page, S. J. (2011). Urban tourism research: Recent progress and current paradoxes. Tourism management, 32(1), 1-15.

2. Burtenshaw, D., Bateman, M. \& Ashworth, G. J. (1991). The European city: a Western Perspective. New York: Halsted Press and London: David Fulton Publishers. Historical Research and Tourism Analysis: The Case of the Tourist-Historic City of Jerusalem. [accessed Sep 13, 2021]. Available from: https://www.researchgate.net/ publication/232826941_Historical_Research_and_Tourism_Analysis_The_Case_of the Tourist-Historic_City_of Jerusalem

3. Cammen, H. V. D. (1992). Burtenshaw, D., Bateman, M. and Ashworth, GJ, "The European City: A Western Perspective" (Book Review). The Town Planning Review, 63(4), 447.

4. Безрукова, О., Бутенко, В., Ермаков, В., Котов, И., Мавренков, А., Полунин, К., Рех, Й., Тимофеев, А. (2018). Исследование развития комфортной городской среды в Москве и ведущих городах мира. Июль 2018. Тhе Boston Consulting Group. [accessed Sep 15, 2021]. Available from: https://docplayer.com/89845319-Issledovanierazvitiya-komfortnoy-gorodskoy-sredy-v-moskve-i-vedushchih-gorodah-mira-publichnyy-otchet.html 


\title{
Комфортная городская среда как фактор развития регионального туризма
}

\author{
Яковлев Андрей \\ Факультет «Высшая школа менеджмента», Финансовый университет при Правительстве Российской Федерации, \\ Москва, Россия
}

\begin{abstract}
АННОТАЦИЯ
Проблема исследования и степень исследования. Исследование посвящено выявлению влияния качества городской среды как фактора развития туризма в регионах. Внутренний туризм, как показал опыт с COVID-19, становится как двигателем экономического развития регионов, так и решением проблемы отсутствия возможностей или безопасности здоровья при поездках за границу.

Проблемный вопрос: что такое комфортная городская среда как фактор развития туризма в регионе? В статье рассматривается один из факторов, влияющих на развитие туризма в российских городах. Поэтому, если учесть влияние этого фактора и сосредоточить его также на туристах, возможно ускорить развитие отрасли. Этот фактор комфортная городская среда.

Тема статьи - развитие комфортной городской среды

Цель исследования - выявление закономерностей между уровнем развития городской среды и развитием туризма в регионах и их туристской привлекательностью.

статистический анализ открытых данных Ростуризма по регионам, сравнительный количественный анализ качества городской среды и развития туризма в регионах, общенаучные методы исследования. В статье представлен количественный анализ показателей качества городской среды городов и регионов, а также использована собственная методика расчета туристской привлекательности регионов как внутренних туристических направлений.

Исследование не выявило прямой зависимости между качеством городской среды и туристической привлекательностью регионов. Однако есть основание, что качество городской среды имеет косвенное влияние на эти показатели: туристы не едут напрямую «посмотреть» городскую среду, но развитость городской сети, городской инфраструктуры имеет позитивное влияние на уровень привлекательности и туризма.

Исследование оставляет за собой ряд незакрытых вопросов, среди которых: изменение подхода к оценке привлекательности регионов, выделение из методики расчета индекса качества городской среды элементов, которые больше всего влияют на туристские предпочтения и впечатления, насколько сильно влияние временного лага между началом развития комфортной городской среды и первыми результатами в виде растущего туристского потока (индекс рассчитывается с 2018 года, приоритетный проект утвержден в 2016 году).

Ключевые слова: Комфортная городская среда, туристическая привлекательность, факторы развития.
\end{abstract}

Gautas 20210916

Priimtas 20211010 